\title{
Criterios \\ Evolución de la policromía en los siglos del Barroco. Fases ocultas, revestimientos, labores y motivos
}

Pedro Luis Echeverria Goñi

Universidad del Pais Vasco. Vitoria

\section{Resumen}

Este texto corresponde a la ponencia impartida en el Congreso Internacional sobre Policromía. A escultura policromada religiosa dos séculos XVII e XVIII, celebrado en Lisboa en octubre de 2002. Pese al conservadurismo en las labores de asiento, hemos podido señalar una evolución en las manos de enyesado y los tipos de encarnación a lo largo de los siglo XVII y XVIII. Asimismo prestamos una especial atención a los nuevos revestimientos de imitación metálica y pétrea y a los cincelados que durante el Rococó van a enriquecer al dorado y estofado. Como fruto de varios años de dedicación a esta especialidad pictórica en los siglos modernos, señalamos aquí una evolución de la policromía barroca en este sector del norte de España en tres periodos, la pintura "del natural", la "distensión" barroca y la "moda chinesca", recuperando una terminología de época que coincide, en lineas generales, con la establecida por $F$. Bartolomé para Álava.

\section{Palabras clave}

\section{Policromía}

Esculturas policromadas

\section{S. XVII-XVIII}

\section{Barroco}

Rococó

España

Pintura del natural

Rameado

Moda chinesca

Bronceado

Jaspeado

Cincelado
La que hoy denominamos policromía barroca era designada por Ios propios artistas durante los siglos XVII y XVIII como pintura del Natural, en contraposición a la pintura del Romano o renacentista que, con su carácter fantástico, evocaba la antigüedad clásica. La expresión "conforme al natural" o "imitando en todo el natural" aparece a fines del siglo XVI, se impone en el primer tercio del XVII hasta fines de esa centuria y todavía se emplea en el siglo XVIII referida a las figuras, carnes y paños. Pacheco, tratadista, experimentado dorador y pintor, teoriza en este sentido cuando escribe en 1634-1638 que la naturaleza es "el principal exemplar objetivo de la pintura", por encima del arte y la imaginación ${ }^{1}$. El punto de partida de esta renovación estética es el Concilio de Trento, pudiendo considerar la pintura del natural como una de las expresiones artísticas más genuinas de la Contrarreforma católica.

El tradicional revestimiento de retablos e imágenes con panes de oro se va enriqueciendo a lo largo de este periodo, primero con localizadas combinaciones con jaspes desde el último tercio del siglo XVII, para generalizarse, el jaspeado, el bronceado y el plateado durante el Rococó (Fig. 1). Mediante el barnizado de estas superficies se pretendía competir en brillo con el del dorado bruñido. De la misma forma, el esgrafiado y el estofado, que se han venido sucediendo y alternando desde fines del siglo XV hasta comienzos del XVIII, van a dar paso ya bien entrado el 1700 a labores más plásticas como el cincelado. Durante el Neoclasicismo no sólo desaparece el dorado, sustituido por una pintura que remeda mármoles, sino que se eliminan las labores de dibujo y pincel, limitándose la policromía a unos paños naturales de tonos planos.

El motivo articulador del estofado barroco es, al igual que en la decoración de talla, botánico. Al grutesco fantástico del Renacimiento sucede el rameado (Fig. 2) más naturalista bajo las denominaciones de follaje, cogollo, cardo y subiente, integrando en su ritmo al resto de los motivos, niños y pájaros, y sufriendo un proceso tendente al engrosamiento y rizamiento. Paralelamente se va enriqueciendo la paleta con medias tintas. Su culminación son los jardines de flores, salpicados de caprichos a la chinesca, y las primaveras que, si bien adornaban desde fines del siglo XVI prendas concretas como la túnica de la Inmaculada, sólo se generalizarán en pleno siglo XVIII. Como señala Francisco Martínez en un Diccionario de Bellas Artes de fines del siglo XVIII: "Un jardin sembrado de flores puede mirarse como la paleta de la naturaleza", ya que en otros elementos "están los colores quebrados, los matizes confundidos, las degradaciones insensibles"'?.

Si el oro, metáfora de lo sagrado, nos transporta a un ambiente sobrenatural, el objetivo del estofado y encarnado de los siglos XVII y XVIII es transformar las tallas, vestidas con lujosas indumentarias de época, en seres de carne y hueso. No podemos olvidar, por último, el decisivo papel estético que juegan las combinaciones cromáticas y lumínicas de dorados, jaspeados, bronceados, plateados y barnizados, reservando siempre al color la imprescindible misión de relajar los sentidos en esas abrumadoras superficies doradas que son los retablos. 


\section{8 - 099 \\ Criterios}

Evolución de la policromía en los siglos del Barroco.

Fases ocultas,

revestimientos, labores

y motivos

PH45 - Octubre 2003
1. Revestimientos. Dorado, plateado y jaspeado.

2. Rameado.

3. Enyesado. (Serv. Rest. Dip. Álava)

4. Bol pajizo o amarillento.
Para la elaboración de este panorama hemos consultado casi un centenar de condicionados y contratos de policromía de los siglos XVII y XVIII, tanto de documentación propia como de colecciones de fuentes y otros apéndices documentales de Navarra, País Vasco, La Rioja, Burgos, Valladolid, Cantabria y Aragón ${ }^{3}$. Estos territorios de la mitad norte de la Península, situados entre el Cantábrico y el Ebro, presentan también en policromía una cierta identidad artística, como ya lo indicaba Francisco Pacheco a fines del primer tercio del siglo XVII ${ }^{4}$, en un espacio que sería bien definido para nuestra historia del arte por el alemán G. Weise ${ }^{5}$. Debido al elevado número de documentos consultados y al carácter repetitivo de algunas de las cláusulas técnicas, hemos seleccionado tres condicionados y contratos modélicos que, fechados en 1636,1709 y $1747^{6}$, reflejan con bastante fidelidad los tres periodos de la policromía barroca en esta zona norteña en obras que, además, la han conservado. Los textos manuscritos revisados nos proporcionan un amplio glosario de términos que hemos adoptado en nuestro texto, por lo que no aparecen entrecomillados.

\section{Estado de la cuestión bibliográfico}

Aún cuando han transcurrido más de cincuenta años desde la publicación de los primeros estudios de $\mathrm{M}^{\mathrm{a}}$ Elena Gómez Moreno y Juan José Martín González sobre policromía ${ }^{7}$, son todavía muy pocos los historiadores de arte que han seguido sus pasos. En las líneas que siguen vamos a intentar recoger las principales aportaciones al mejor conocimiento de la pintura de talla en los siglos del Barroco. Tras la pionera obra de Martín González $z^{8}$, los mejores trabajos con base documental que versan sobre la evolución de la policromía barroca en retablos de la mitad norte de España se han realizado en los doce últimos años en el Departamento de Historia del Arte de la Facultad de Filología y Geografía e Historia de la Universidad del País Vasco en Vitoria, siguiendo la línea y la metodología trazadas en nuestra tesis sobre Policromía del Renacimiento en Navarra ${ }^{9}$. Así, entre las diferentes tesis que se han ocupado de la retablística barroca en nuestro ámbito, debemos destacar la de J.J. Vélez, publicada en 1990, quien en el apartado dedicado a la policromía señala y caracteriza ya los tres periodos, contrarreformista, barroco y rococó ${ }^{10}$. La primera sintesis que aborda monográficamente la policromía moderna hispana corresponde a 1992, cuando tracé una periodización de la barroca en paralelo a la evolución del retablo en tres momentos, contrarreformista (c. 1580-1675), en dos fases, barroco (c.16801735) y rococó, hasta 1775 aproximadamente ${ }^{11}$. Se recogieron aquí las denominaciones de época como "pintura del natural o de la cosa viva", "papeles de todas las colores", "patrones de telas de Italia", "distensión" o "motivos a la chinesca", recuperamos otras como "rameados" y se caracterizaron los procesos, paleta, labores y motivos que, en sus rasgos básicos, se presentaron en el citado congreso.

Con motivo de un proyecto de investigación sobre pintura, dorado y estofado de la primera mitad del siglo XVII en Álava, finan- ciado por la Universidad del País Vasco, Vélez Chaurri y Bartolomé García dieron denominación documental por vez primera a cuatro periodos policromos en el Barroco, llamados del natural (c.1580-1630), decoro, hasta 1675, luces y sombras hasta 1735 y chinesca o rococó, hasta $1775^{12}$. En este libro quedan valorados certeramente los pintores Pedro Ruiz de Barrón y Diego Pérez y Cisneros y sus realizaciones más destacadas en unos de los momentos de más calidad en la retablística policromada de este territorio, estrechamente vinculada a ese centro de referencia artística que es la ciudad de Valladolid.

En un curso sobre policromía en los siglos XVII y XVIII que, por encargo de la Asociación de Conservadores-restauradores de Bienes Culturales de Gipuzkoa, impartí en San Sebastián los dias 24 y 25 de septiembre de 1999, desarrollé los aspectos históricos, técnicos y estilísticos de este procedimiento en Gipuzkoa, denominando a los tres periodos citados, pintura del natural, la distensión barroca y la moda chinesca, y recogiendo por vez primera los nombres de los pintores y obras más importantes. En el capitulo dedicado a la policromía entre los siglos XIV y XIX de un libro sobre los retablos más sobresalientes del País Vasco (2001) se analizan esos tres periodos dentro de la secuencia completa de esta especialidad pictórica desde el Gótico hasta el Neoclasicismo, así como los talleres, maestros y obras más representativos ${ }^{13}$.

Si exceptuamos los pioneros y excepcionales estudios de Sánchez-Mesa sobre las policromías granadina y de Alonso Cano ${ }^{14}$, que han interesado tanto a historiadores del arte como a restauradores y artistas, no contamos en España más que con un gran trabajo de investigación que versa monográficamente sobre la policromía barroca, la tesis que en el año 2000 fue defendida en esta Universidad del País Vasco por Fernando Bartolomé con el título de La policromía barroca en Álava. En ella trazó una evolución en tres periodos que denomina pinturas del natural, de luces y sombras y rococó o chinesca, los mismos que analiza en una comunicación presentada a las Jornadas de Revisión del Arte Barroco del año 2000 sobre la policromia barroca en el País Vasco ${ }^{15}$, donde cita además los pintores y obras más representativos. La tesis citada ha merecido ser publicada recientemente en este año 2002 por la Diputación de Álava en una cuidada edición, encabezada por un índice modélico de un trabajo histórico-artístico y profusamente ilustrada con láminas de detalles polícromos, cuadros y fuentes gráficas. Entre sus muchas virtudes deseo destacar, junto a la evolución ya citada, otros apartados como el de los modelos ornamentales que posee entidad por si mismo, tanto por el estudio de los motivos como por los complejos esfuerzos de identificación de jarrones, cartelas y rocallas. Por la misma razón resulta interesante el apartado relativo a las imitaciones textiles de las estofas con diseños de telas de Italia, tejidos de Lyon o sedas valencianas. Todos estos modelos gráficos confirman una vez más el carácter internacional de esta modalidad pictórica ${ }^{16}$. 

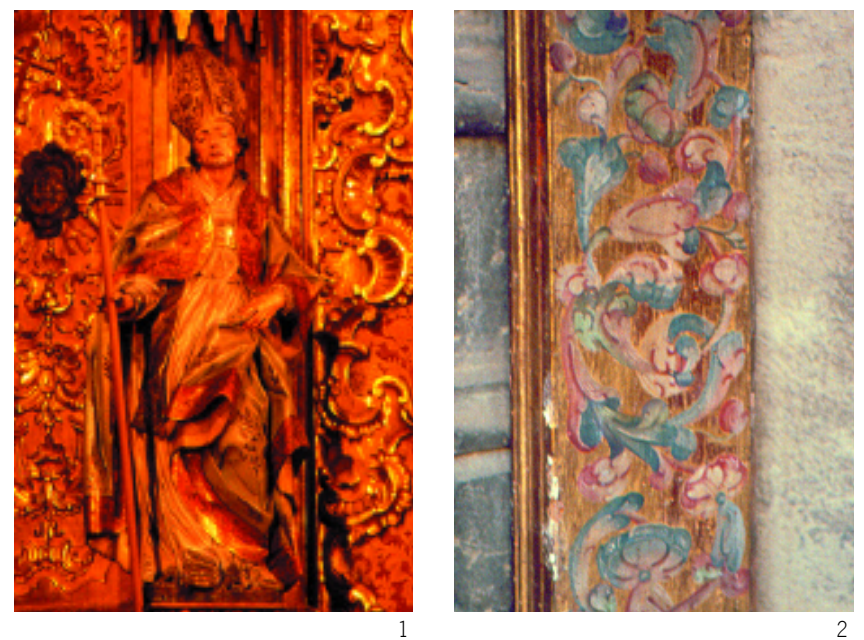

\section{Fases ocultas y de revestimiento en el proceso polícromo}

Como oficio artesanal basado en la experiencia, la policromía se fundamenta en un buen conocimiento de los materiales, la compatibilidad entre ellos y su permanencia posterior. Sin embargo, pese a que las labores de asiento y recubrimiento no admiten demasiadas variaciones, hemos podido establecer una evolución en algunos procedimientos tan consuetudinarios como el enyesado y el encarnado. El revestimiento de imitación metálica y pétrea de la obra de talla requería una serie de labores previas de impermeabilización e igualación de la superficie de la madera que, si bien no son visibles al final del proceso, resultaban imprescindibles para que unos materiales tan distintos abrazaran entre sí y no saltaran con el paso del tiempo. Estas operaciones fueron básicamente el picado de nudos con ajos, el encolado, el emplastecido de juntas y el enlenzado, siendo la materia primordial para todas las templas la cola de piel de retazo de Baldes. Se cocía en una proporción de 100 gramos en tres cuartos de litro de agua y se aplicaba con pincel, primero una mano de cola flaca y luego una o más de cola fuerte, siempre en el sentido de la veta de la madera.

El aparejado propiamente dicho consistía en la aplicación asimismo con pincel de varias manos de yeso grueso, yeso mate y bol. El número de manos del enyesado osciló en la cronología que nos ocupa entre 3 y 6 , dependiendo de la época y las zonas a enyesar (Fig. 3). La norma habitual durante el siglo XVII fue dar cinco manos, reduciéndose el número en el XVIII, primero a tres manos en condicionados de la década de los 30 para fijarse en cuatro entre 1740 y 1770, en plena cronología rococó. Se debía recorrer toda la arquitectura y la talla sin confundir los sentidos, intentando no encubrir las zonas delicadas, por lo que esta fase requería del pintor un cierto sentido plástico. Otras condiciones eran el secado entre mano y mano, la aplicación de cada baño cruzado respecto al anterior y el escofinado o repaso de las superficies con hierros para que éstas quedaran tersas.

En las zonas destinadas a ser doradas se aplicaban varias manos de bol o arcilla rojiza en operación conocida como embolado. El más apreciado en estas latitudes fue el bol de Llanes porque con él salía oro de buen color y sin manchas, muy por encima del bol pajizo o amarillento (Fig. 4) que, sin embargo, ahorraba panes y era más resistente a la abrasión. En alguna ocasión fueron usados mezclados, primero el pajizo para asiento y luego el rojizo. Asimismo parece que, pese a las prohibiciones, el bol amarillo fue utilizado como asiento del dorado mate en el siglo XVIII y el bol gris sirvió como base adecuada para zonas a platear. En este pro-
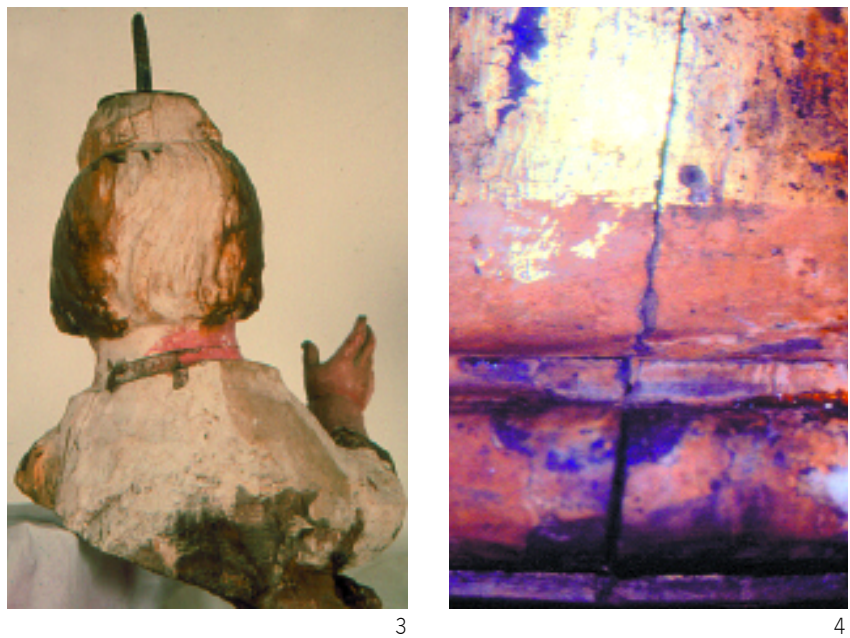

ceso resultaba clave para la correcta adhesión del pan de oro el secado que no había de ser ni muy rápido ni muy lento, el pulido con frotadores de cerdas y, finalmente, la aplicación de las templas necesarias compuestas de clara de huevo más agua.

Sabido es que la pintura es el arte de la mímesis por excelencia ya que, mediante el color, no sólo imita a las otras artes sino que puede llegarse a imitar a si misma, es decir a otros procedimientos. Esa especialidad pictórica que es el dorado y estofado de talla confirma una vez más ese carácter mimético, pues los pintores-doradores no sólo dieron vida y expresión a tallas inanimadas, sino que ennoblecieron un material humilde como es la madera con revestimientos e imitaciones metálicos y pétreos ${ }^{17}$, que hacen que parezcan obras de oro, bronce, plata, jaspe, mármol y concha.

El dorado bruñido es la fase fundamental del proceso policromo, pues inunda todas las superficies, combinándose con el color en el siglo XVII y con bronceados, plateados y jaspeados en los retablos dieciochescos $^{18}$. Los panes de oro empleados repiten el tamaño de unos ocho por ocho centímetros de lado, en tanto que experimentan una disminución de la ley y un mayor engosamiento a lo largo de esta cronología. Dejadas de lado las denominaciones locales de procedencia, encontramos las de oro de Milán y de Flandes en el siglo XVII y la de Madrid, que se impone para las mejores obras a mediados del siglo XVIII. Los doradores debían realizar empalmes precisos entre los panes (Fig. 5), si bien en algunas zonas alejadas de la vista se omitian o se disponían muy separados para ahorrar láminas (Fig. 6). La superficie se bruñia con piedras de ágata y bruñidores de diente, lo que disimulaba las juntas y proporcionaba a los retablos el brillo característico. El dorado mate con aceite de nueces espesado se aplicó a algunas zonas como los cabellos de la Virgen y los ángeles casi sin imprimación.

A mediados del siglo XVIII se generaliza el bronceado (Fig. 7) o corla de bronce sobre oro, una moda extranjera procedente de Italia ${ }^{19}$ y difundida a través de la Corte de Madrid. Su tono mate permitió establecer nuevas contraposiciones con el oro bruñido, pues reservándolo para los fondos hacia que los adornos de talla parecieran de oro macizo. Contrastan las frecuentes prohibiciones al uso de plata en los retablos con la comprobación del uso del plateado con corlas verdes y grises en zonas especificas como las nubes, objetos metálicos, enveses de prendas, pedestales, mesas y algunas molduras.

A fines del XVII y comienzos del XVIII se introduce el jaspeado, es decir, la imitación de piedras y jaspes con sus vetas, motas, venas y virado ${ }^{20}$ (Fig. 8). Este procedimiento se combina primero con el dorado, para ir imponiéndose sobre éste en muchos conjuntos del Rococó y triunfar finalmente con la simulación de mármoles du- 


\section{$100-101$}

\section{Criterios}

Evolución de la policromía en los siglos del Barroco. Fases ocultas,

revestimientos, labores y motivos

\section{PH45 - Octubre 2003}
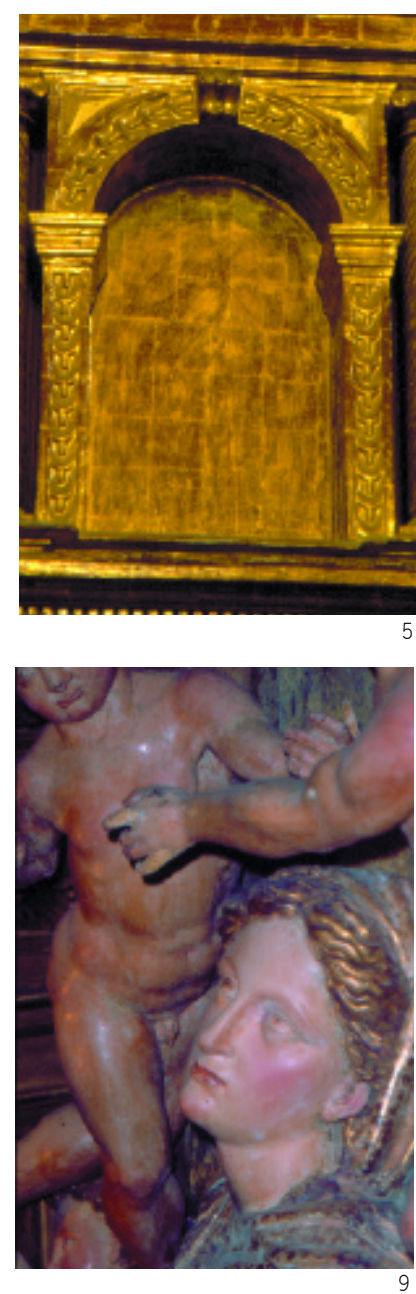

5. Empalmes de panes de oro.

6. Panes separados (S.R.D.A.).

7. Contraposición entre bronceado y oro bruñido.

8. Jaspeados.

9. Encarnaciones mates (siglo XVII).

10. Encarnación a pulimento (siglo XVIII).

11. Trilogía contrarreformista o "papel de todas las colores".

12. Brutesco (Larrión y Pimoulier).
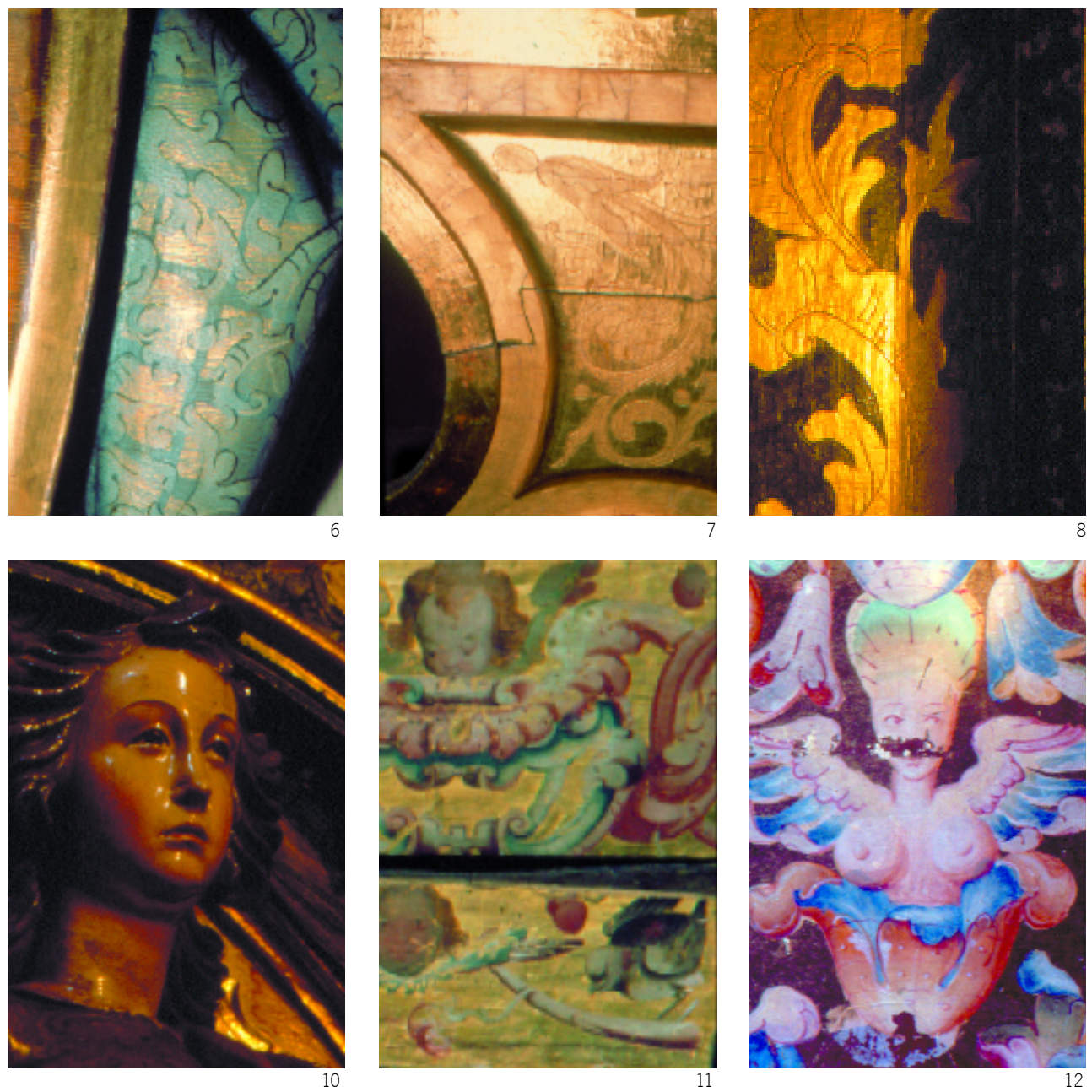

rante el Neoclasicismo. Las imitaciones más usuales fueron las de piedra lapislázuli, roja, almendrada, pórfido, ágata, jaspes varios y mármoles con sus denominaciones de origen, concha y nácar. Su marco preferente fueron los campos y cajeamientos lisos, creando contrastes cromáticos con las zonas de talla doradas, bronceadas (por ejemplo basas y capiteles) y plateadas. Su barnizado con espíritu de vino ${ }^{21}$ y aguardiente garantizaba su permanencia y otorgaba a los jaspes un brillo que pretendía rivalizar con el del oro.

La policromía de tonos planos fue empleada en imágenes, grupos y bustos de Pasión como el Ecce Homo, la Dolorosa o el Nazareno y, de forma más específica, durante el periodo rococó se generalizan los denominados "paños naturales", concentrándose las únicas labores en cenefas y galones. Suele ser aplicada en el taller del escultor por un pintor familiar, un colaborador próximo o bajo su directa supervisión. Son famosos los casos de algunos escultores andaluces que, como Alonso Cano, José de Mora o José Risueño, policromaban sus propias imágenes ${ }^{22}$. Para este tipo de policromía no se precisa sino un aparejo simple que valora mejor los volúmenes y consta de una simple mano de gíscola y pintura al óleo. Los colores son medias tintas, brillantes y metalizados como azules, rojos y amarillos. Su complemento natural fueron diferentes postizos y añadidos como ojos de cristal, lágrimas, pelucas, telas encoladas y encajes.

Por encarnación entendemos un tipo de pintura al óleo que imita la carne y la piel humanas en las zonas desnudas. Las partes destinadas a ser encarnadas recibían una preparación más fina que las otras zonas. Solían ser las primeras zonas en ser imprimadas y las últimas en recibir los acabados que daban a las tallas la última vida y la expresión ${ }^{23}$. Durante estos siglos se comprueba la utilización de encarnaciones mate, a pulimento y mixta. La carnación mate (Fig. 9) es la que mejor imita el natural y respeta los perfiles de la talla, permite matizar y puede ser retocada varias veces. En contrapartida es menos consistente y sufre desconchamientos, al asentarse sobre un aparejo simple a base de una mano de cola y dos o tres de albayalde. La de pulimento (Fig. 10) es muy consistente y deja una superficie tersa y brillante, pero tiende a la idealización. Su aparejo se compone de dos o tres manos de yeso grueso y otras tantas de mate. Se trataba de una 
13. Tarjeta con país.

14. Brocado con motivos con "relievo" (S.R.D.A.).

15. Piedras contrahechas y perlas.

16. Miniatura de la Esperanza.

17. Labores esgrafiadas.

18. Encarnaciones mates.

19. Contraposición entre campo dorado y talla coloreada.

20. Contraposición entre un retablo dorado y las imágenes pintadas y estofadas.
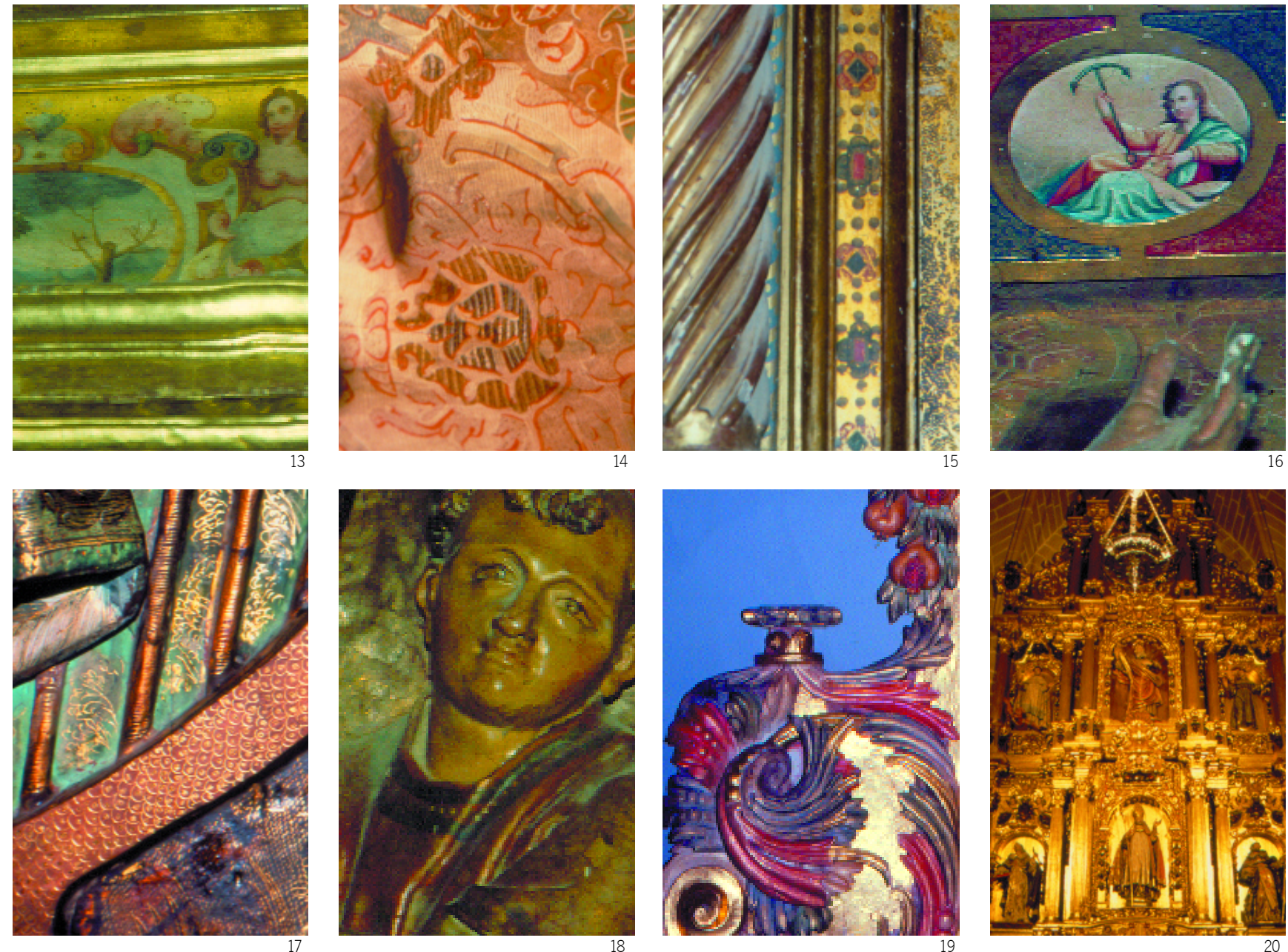

pintura al aceite de nueces clarificado al sol, en la que se empleaban pigmentos claros como el bermellón o el carmín para las carnaciones sonrosadas de mujeres y niños y otros como el almagre o la sombra para las más cetrinas de los ancianos o los penitentes, adecuándose así al decoro de las distintas edades.

En nuestro ámbito de estudio la mate se impone en dos momentos del periodo aquí analizado, a fines del primer tercio del siglo XVII, siguiendo el modelo impuesto por Valladolid y en el segundo tercio del 1700, según se aplicaba en la Corte de Madrid. El uso de la encarnación a pulimento se especifica en contratos de las últimas décadas del siglo XVI, se mantiene e incluso alterna con la mate en el XVII y se impone en algunos momentos e iconografías del siglo XVIII. A fines del siglo XVII y, sobretodo, en el primer tercio del XVIII se generaliza una encarnación mixta o doble, primero a pulimento y luego mate, uniendo las ventajas de ambas. Con medias tintas y acabados a punta de pincel al óleo se imitan ojos, cejas, pestañas, cabellos y barbas. La Virgen y los ángeles muestran sus cabellos peleteados con oro al mixtión, y a veces los ancianos de cabello canoso con plata.

Ya que la policromía consiste básicamente en el revestimiento de la talla con aparejos, oro y colores diversos, creemos oportuno concluir este primer punto con una relación de los pigmentos más utilizados en sus obras por los pintores-doradores de estos siglos, entresacada de inventarios de bienes y condicionados y otros documentos que, en algunas ocasiones, se acompaña de las denominaciones de origen ${ }^{24}$. Entre los rojos cabe citar los carmines de Indias, Florencia y el de Honduras, también Ilamado cochinilla, bermellón, almagre de Levante, minio y diferentes tierras rojas. Los azules más mencionados son el fino de Sevilla, los de cenizas, esmalte, cabeza y en el siglo XVIII el ultramarino, las cenizas de Hungría y el Prusia, que hace su aparición a fines del primer tercio del 1700. El añil es el más citado entre los violáceos. De los verdes se repiten el montaña claro, vejiga, tierra, verdacho, cardenillo y el verde esmeralda (siglo XVIII). Entre los amarillos encontramos una mayor variedad con colores como el ancorca oscuro de Flandes, genoli, jalde u oropimente, gutiambar, ocres claros y ocre de Holanda (siglo XVIII). Se citan también diversos pardos y tierras como la sombra de Venecia. El azarcón de Levante mostraba un matiz anaranjado. El negro aparece sin calificativos y, puntual- 


\section{$102-103$ \\ Criterios}

Evolución de la policromía en los siglos del Barroco.

Fases ocultas,

revestimientos, labores

y motivos

\section{PH45 - Octubre 2003}

mente, como humo de pez, y nunca falta en los talleres de los pintores un buen número de libras de albayalde o blanco de plomo.

\section{Evolución de la policromía barroca. Labores y motivos}

La policromía barroca no es sino una consecuencia más del espíritu emanado del Concilio de Trento, trasladado a las diferentes diócesis por las Constituciones Sinodales. Básicamente se trata de una manifestación contrarreformista que supuso la depuración y reducción del repertorio ornamental para aproximar las tallas al modelo real. Desde las últimas décadas del siglo XVI hasta 1775 aproximadamente se sigue esta dirección artística, pero se adquiere un gran virtuosismo técnico y se amplian los procedimientos. Atendiendo principalmente a la fase más evolutiva y visible del proceso polícromo, el estofado, distinguimos en esta área del norte de España tres grandes periodos en la evolución de la policromía barroca, la pintura del natural (c.1580-1675), la distensión barroca (c. 1675-1735) y la moda chinesca (c.1740-1775). Se trata en cualquier caso de fechas referenciales que admiten, como no podía ser de otra forma en un oficio artesanal, todo tipo de arraigos y pervivencias según los talleres y áreas geográficas, como ocurre por ejemplo en el periodo final que se prolonga en algunos casos en plena cronología neoclásica.

Los documentos designan como pintura del natural y de la cosa viva (c. 1580-1675) a un tipo de pintura que, en reacción a los motivos fantásticos del Renacimiento, reduce su temática a otros más creibles. Las superficies planas de los nuevos retablos romanistas y clasicistas se cubren de papeles de todas colores o trilogía contrarreformista (Fig. 11), codificada a base de rameados o tallos vegetales, niños y pájaros del país, estofados sobre oro mediante la tripleta luminifera de carmín fino, azul ceniza y verde montaña. No desaparece de los contratos la alusión a los brutescos o brulescos (Fig. 12), manteniéndose todavía ciertas figuras de niños y ángeles que salen de tallos y cálices florales. Centran algunas de estas composiciones cartelas correiformes de estirpe manierista que, sostenidas por tenantes, sirven de marco para deliciosas miniaturas con paisajes (Fig. 13), inscripciones y símbolos.

Los modelos para los rítmicos roleos vegetales estofados los encontramos ya en "frisos" de fines del siglo XVI como los de B. Pittoni, G.B. Mutiano o Martín Pleginck (1594) y, especialmente, en los ya más carnosos del siglo XVII como los de B. d'Agnelli, D. Bonaveri o la colección de dibujos clásicos de Jacques Stella, grabada en 1657. Siguiendo el ritmo de estos tallos vegetales se intercalan pájaros en tiras verticales como la de Adrián Muntinck (1597) y en frisos como los de Hans Jensen (1630). Por último, encontramos una modélica trilogía contrarreformista en un grabado del citado Adrián Muntinck de $1615^{25}$.

Si bien se constata desde las últimas décadas del siglo XVI la imitación de telas de oro naturales con rameados y cogollos, será duran-
21. Contraposición entre campo jaspeado y talla dorada (S.R.D.A.).

22. Jardin de flores.

23. Contraste entre fondo bronceado y motivos dorados. 24. Fondos jaspeados y talla dorada (S.R.D.A.).

25. Rocallas cinceladas.

26. Jardin de flores (S.R.D.A.).

27. Telas de paños naturales y galón dorado.

28. Encarnación a pulimento.

te la centuria siguiente cuando se alcanzó un verismo excepcional en la imitación textil, que colaboraba en la caracterización de cada personaje según la norma de la propiedad, gravedad y decoro. Los ropajes, en los que se diferenciaban las prendas, el haz y el envés, imitaban lujosas telas naturales como brocados de seda con fondos rajados (Fig. 14), damascos y gasas, entre otros. El principal objetivo fue la imitación de labores en relieve como los sombreados, realzados, picados de lustre, brocados de tres altos, en tanto que las cenefas fueron el marco canónico de piedras contrahechas, perlas (Fig. 15) y brutescos. Como modelos se emplearon patrones propios de la estampación textil al uso en las fábricas de tejidos de seda, de las que las más importantes radicaban en Valencia, Toledo, Granada y Sevilla. Todo lo relacionado con su confección y labrado sería regulado y unificado por ordenanzas en la segunda mitad del siglo XVII.

Una artesanía como ésta se aproxima a arte en las deliciosas miniaturas de algunos fondos y marcos geométricos, donde aparecen con frecuencia personajes sagrados, santos, ángeles, virtudes (Fig. 16) y pequeñas escenas. Con el grafio se dibujaron labores más artesanales como rajados, ojeteados, picados, escamados (Fig. 17), ondulados, morescos y otras, siendo sus marcos canónicos los fondos, encuadramientos, enveses de mantos y primeros términos. Si durante los últimos años del siglo XVI y comienzos del XVII los documentos consignan la obligación de realizar las encarnaciones a pulimento, a fines del primer tercio del siglo XVII se generalizan en nuestro ámbito las encarnaciones mates (Fig. 18), siguiendo la moda de Valladolid, según lo demandaba el tratamiento más natural de las diferentes edades.

El abigarramiento progresivo de talla botánica en el retablo churrigueresco propició una nueva policromía, debido a la reducción de las superficies lisas aptas para la realización de labores estofadas. Los retablos con prolija talla rizada se convirtieron así en ascuas de oro, lo que obligó a los pintores-doradores a establecer diferentes contraposiciones entre las zonas doradas, coloreadas y jaspeadas. Si bien no existe un término documental que designe las modas polícromas de este momento, que siguen persiguiendo la imitación del natural, lo hemos llamado pintura de la distensión barroca (c. 1680-1735), ya que todas las labores pretendian en sus propias palabras la separación del oro por medio del color para la relajación o distensión de los sentidos.

El contraste más recurrente fue el que se estableció entre los campos lisos dorados y la talla pintada y estofada (Fig. 19). Así capiteles, ménsulas, pinjantes, escudos, hojas de parra y uvas recibieron colores alternantes, rojo, verde y azul, abiertos con diferentes labores de grafio, y también plata reglasada. Encontramos asimismo algunos retablos totalmente dorados sin colores ni labores, concentrando los estofados en tallas y relieves (Fig. 20).

Una última forma de contraposición es la que se comienza a ensayar en este periodo entre los campos jaspeados de lapislázuli, ágata, pórfido, concha o nácar, y la talla dorada (Fig. 21). De esta forma, rivalizaban en brillo mediante los barnizados con es- 

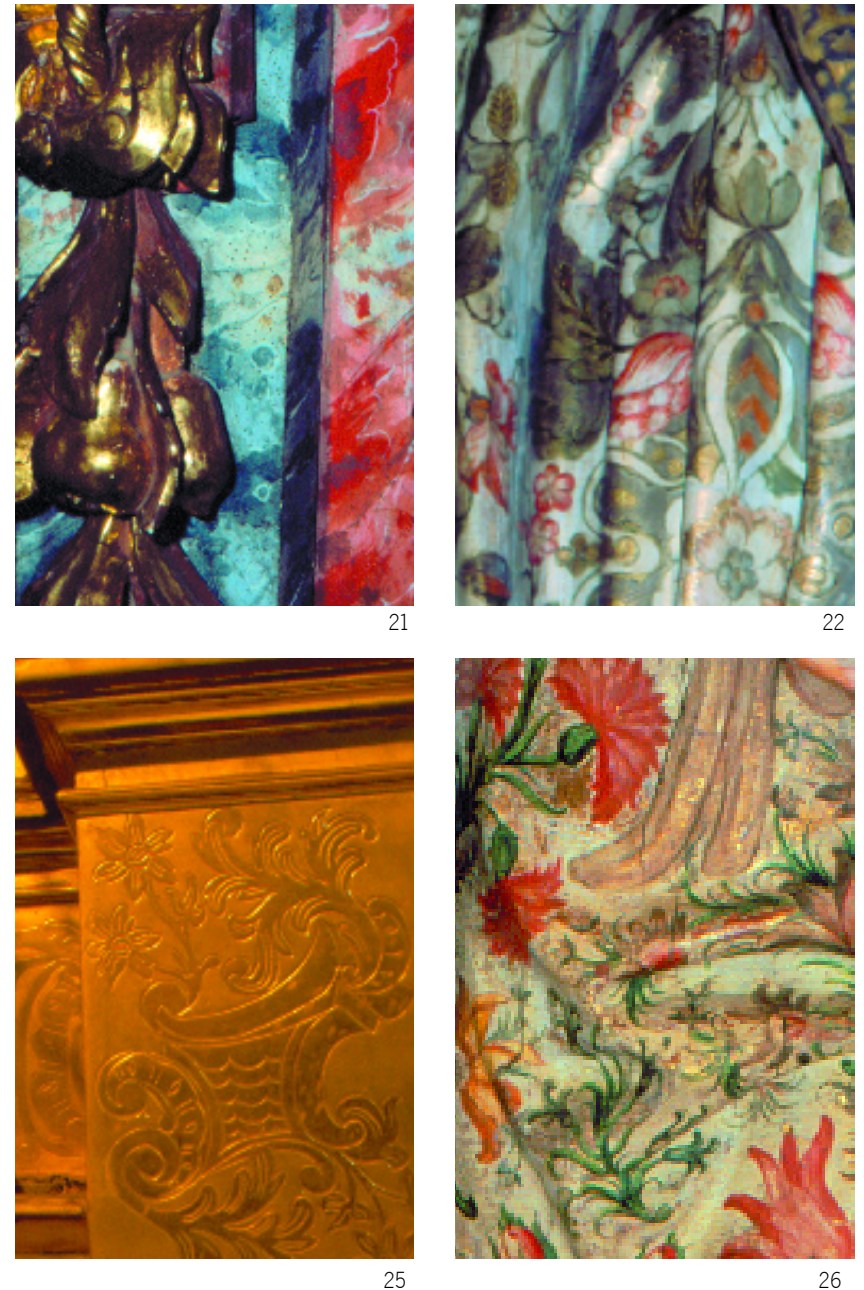

26
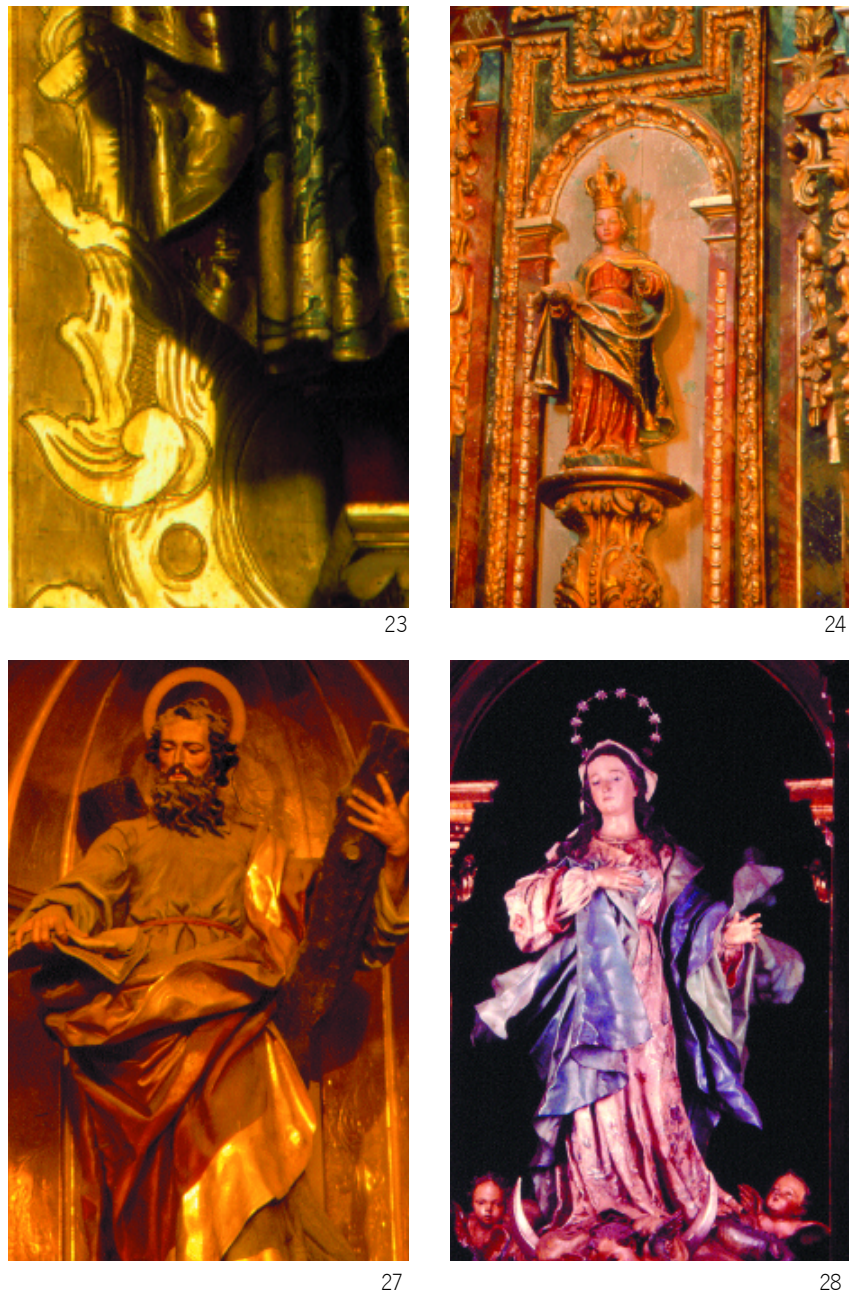

piritu de aguardiente y los bruñidos respectivamente. Asistimos ahora a la elaboración de nuevos juegos cromáticos entre las prendas en tanto que las orillas se decoran con motivos variados como juegos de niños sobre oro. Continúan los rameados y los brutescos, cada vez más engrosados, que dan paso a las aguadas, primaveras y jardines de Italia (Fig. 22) con una colorista paleta a la que se incorporan el ultramarino, el prusia y la cochinilla o carmín de Honduras. Caracteriza este momento del primer tercio del siglo XVIII una encarnación doble con una primera mano a pulimento, que la hace más consistente y perdurable, y luego otra mate con buenos aceites que guarda mayor fidelidad con el natural. Son frecuentes ahora los ojos de cristal insertos.

A un nuevo concepto de retablo, planteamiento programático y repertorio ornamental va a acompañar también una policromía novedosa, que los propios maestros denominaban la moda chinesca (c.1740-1775), dentro del Rococó internacional. A mediados del siglo XVIII, el retablo churrigueresco da paso a los organismos borrominescos, de dinámicas plantas y cornisamientos que dejaron nuevamente campos lisos adecuados para el revestimiento decorativo. A la espectacularidad de los modelos de retablo cortesano de cascarón contribuyeron decisivamente las combinaciones de dorado, bronceado, plateado y jaspeado, así como los dibujos en ellos cincelados. Se establecía así un buen número de contraposiciones entre bruñido y mate no sólo de oro sino de nuevas formas de recubrimiento artístico. El objetivo era siempre el contraste entre claros y oscuros, entre tonos fríos y cálidos.

Los condicionados de policromía de mediados del siglo XVIII recogen la aplicación del bronceado (Fig. 23) en zonas concretas del retablo como los lisos y vaciados, según se daba en Madrid en moda procedente de Italia. Así denominaban al baño de bronce sobre el oro mate que servía para establecer nuevos contrastes con el dorado bruñido de los adornos y salientes de talla. Aumentan asimismo los plateados y corlados en zonas como las nubes con chillones dorados, los enveses de algunas prendas, guirnaldas y frontales de altar. Gana terreno, imponiéndose en numerosos campos el jaspeado (Fig. 24) con sus motas y venas que hace destacar más la talla, filetes y tarjetas dorados o plateados. Las imitaciones más frecuentes fueron las de lapislázuli o azul fuerte, pórfido, rosado, almendrado y verdoso. No faltan camino del Neoclasicismo los que imitan mármol blanco, concha y nácar que Jovellanos denominó gráficamente conjuntos de leche y oro. Solían ser barnizados con espíritu de vino o quintaesencia de aguardiente con grasilla o goma, y charol para disimular los roces y para aproximar su brillo al del oro.

La técnica más original del periodo es el cincelado (Fig. 25) o dibujo inciso realizado con un punzón sobre el yeso o el oro en los campos lisos del retablo y estampado sobre los vestidos. Estos adornos a la moda chinesca tienen su origen en decoraciones de gabinetes chinos de los palacios de Madrid y se habian introducido por el Levante español como los marcos de rocalla, espejos, guirnaldas, ramos, símbolos, anagramas y otros caprichos saineteados. Estos motivos que caracterizan al Rococó se difundieron a través de grabados ornamentales franceses y alemanes de los años 1730 y 1740 como los de Boucher, Huquier, Babel, Delajoue, Mondon o Cuvillies $^{26}$ y alemanes de la década de 1750 en adelante como los de Wachsmuth, Baumgartner, los Klauber, Habermann o Göz $z^{27}$. En España tuvieron gran aceptación y difusión los modelos diseñados en la fase inicial prerococó por el aragonés Carlos Casanova (+ 1771), pintor de cámara de Fernando VI 


\section{$104-105$}

\section{Criterios}

Evolución de la policromía en los siglos del Barroco.

Fases ocultas,

revestimientos, labores

y motivos

\section{PH45 - Octubre 2003}

y grabador, en su Libro de Ornatos, inbentarios y abiertos, impreso por Juan de Aldaco en San Sebastián hacia $1720-1725^{28}$, asi como las orlas de portadas, marcos de estampas y otros motivos del religioso mínimo fray Matías de Irala (+ 1753), autor de un Método sucinto y conpendioso de cinco simetrías apropiadas a las cinco órdenes de arquitectura, adornadas con otras reglas útiles (1739), que incluye láminas con ornamentos barrocos y una, la 25, con tempranos motivos del Rococó ${ }^{29}$.

A estas modas imperantes en la época corresponden las telas de seda estofadas con flores (Fig. 26) y otros caprichos curiosos con medias tintas nuevas como el blanco hueso, carmín rosáceo, verde esmeralda y azul Prusia. En algunas de las piezas más sobresalientes se imitaron finas telas estampadas en la Real Fábrica de los Cinco Gremios Mayores de Madrid. Bien superado el ecuador del 1700 hacen su aparición las telas de paños naturales o colores planos con galones dorados (Fig. 27), imitando así otra moda impuesta por la Corte de Madrid. Los galones suelen presentar tres dedos de oro y cuatro de labor moderna de dibujos cincelados. En este periodo predomina la encarnación mate al aceite, más natural o barroca, en santos, niños y ángeles, según práctica coetánea de la Corte. También encontramos encarnaciones a pulimento (Fig. 28) de matiz lechoso, asimismo, al aceite, principalmente en la Virgen y en determinados crucificados. En algunos casos se obtenía la expresión decidida de las imágenes mediante la inserción de ojos de cristal.

\section{NOTAS}

'PACHECO, F. El Arte de la Pintura (1649). Edición, introducción y notas de B. Bassegoda y Hugás Cátedra, Madrid, 1990, p.79

2 MARTINEZ, F. Introducción al conocimiento de las Bellas Artes o Diccionario manual de pintura, escultura, arquitectura, grabado. Madrid, 1788, p. 190. Voz Flores

${ }^{3}$ Resultan especialmente ilustrativos algunos corpus como los de GARCIA CHICO, E. Documentos para el estudio del Arte en Castilla. T. Tercero, 1 y II. Pintores. C.S.I.C. Valladolid, 1946 y GONZA LEZ ECHEGARAY, Ma C. Documentos para la Historia del Arte en Cantabria. Escultores, entalladores y pintores de los siglos XVI al XVIII, 2 vols. Santander, 1971 y 1073

${ }^{4}$ PACHECO, F. Op. cit., pp. 504-505. Aparejos de Castilla

${ }^{5}$ WEISE, G.: Die Plastik der Renaissance und des Frübarok im nördlichen Spanien. Aragón, Navarra, die Baskisch Provinzen und die Rioja, Y. Tübingen, 1957. Ibid.: La plástica del Renacimiento y del prebarroco en la España Septentrional: Aragón, Navarra, las provincias vascas y La Rioja. Resumen en castellano de 1960

${ }^{6}$ ANDRES ORDAX, S. Gregorio Fernández en Álava. Vitoria, 1976, pp. 73-84. Condicionados y contrato para el dorado del retablo mayor de San Miguel de Vitoria (1636). HUARTE Y JAUREGUI, J.M. "Los retablos del convento de las Monjas Recoletas de Pamplona". Boletín de la Comisión de Monumentos de Navarra (1927), pp. 317-321. Contrato y condicionado del retablo mayor y dos colaterales del convento de Agustinas Recoletas de Pamplona (1709). Archivo Diocesano de Pamplona. Ollo $\mathrm{C} / 1616, \mathrm{n}^{\circ}$ 2. Condicionado para el dorado, bronceado y estofado del retablo mayor de la na. Ollo C/1616, nº́ 2. Condicio

${ }^{7}$ GOMEZ MORENO, Mª E. La policromía en la escultura española. Madrid, 1943. MARTIN GONZALEZ, J.J. "La policromía en la escultura castellana". Archivo Español de Arte, XXVI (1953), pp. 295-312

${ }^{3}$ MARTIN GONZALEZ, J.J. Escultura barroca castellana. Madrid, 1959, pp. 39-46. Policromía de los siglos XVII y XVIII

${ }^{9}$ ECHEVERRIA GOÑI, P.L. Policromía del Renacimiento en Navarra. Pamplona, 1990

${ }^{10}$ VELEZ CHAURRI, J.J. El retablo barroco en los limites de las provincias de Álava, Burgos y La Rioja (1600-1789). Vitoria, 1990, pp. 123-124

${ }^{11}$ ECHEVERRIA GOÑI, P.L. Policromía renacentista y barroca. Cuadernos de Arte Español, 48. Historia 16. Madrid, 1992, pp. 26-31
${ }^{12}$ VELEZ CHAURRI, J.J. y BARTOLOME GARCIA, F.R. La policromía de la primera mitad del siglo XVII en Álava. Pedro Ruiz de Barrón y Diego Pérez y Cisneros (1602-1648), Miranda de Ebro, 1998, pp. 10 y 14.19

${ }^{13}$ ECHEVERRIA GOÑI, P.L. "Evolución de la policromia entre los siglos XIV y XIX". Erretaulak/Retablos. Euskadi, I. Ikerketak/Estudios. Catálogos del Centro de Patrimonio Cultural Vasco. Vitoria-Gasteiz, 2001, pp. 339-351

${ }^{14}$ SANCHEZ MESA MARTIN, D. La policromía en las esculturas de Cano, en Estudios del III Centenario de Alonso Cano en Granada. Granada, 1969. Ibid. Técnica de la escultura policromada granadina. Granada, 1971. Como estudio documental merece ser destacado en nuestro ámbito, por lo inusual, el denso artículo de PAYO HERNANZ, R.J. "La policromía en Burgos en el tránsito del siglo XVII a XVIII: el maestro dorador y estofador Lucas de la Concha". Boletin de la Institución Fersiglo XVI, XVIl: 212 (1995) pp. 65 98. Como ejemplo a segir entre los restauradores so percom puede citar el de BARRIO, M. y BERASAIN, I. "Agustín Conde, policromador del retablo de San Juan Bau-
tista de Hernani". Ondare, 19 (2000), pp. 443-453, que constituye un interesante intento de contista de Hernani”. Ondare, 19 (2000), pp. 4434
ciliación de los enfoques histórico y técnico.

${ }^{15}$ BARTOLOME GARCIA, F.R. "Evolución de la policromía barroca en el Pais Vasco". Revisión del Arte barroco. Ondare, 19 (2000), pp. 455-470

${ }^{16}$ Ibid.: La policromía barroca en Álava. Vitoria, 2002, pp. 95-182, Modelos ornamentales (126-141, Imitaciones textiles) y 185-203, evolución de la policromía barroca.

${ }^{17}$ Entre las diferentes técnicas pictóricas de la imaginería policromada Gañán Medina ha diferenciado recientemente las de enmascaramiento (estofado y encarnado), las de imitación metálica y pétrea y las de potenciación, es decir, los acabados, bruñidos, pulimentados y barnizados. GAÑNAN MEDINA, C. Técnicas y evolución de la imaginería policroma en Sevilla. Sevilla, 1999, p. 148

${ }^{18}$ El dorado es el revestimiento por excelencia de la talla barroca, pues "color por color, el oro es el que lo tiene más Noble y la simetría en repartirlo es la principal Ermosura", como nos dice en 1760 el pintor riojano Felipe Reoyo en una declaración sobre la pintura del retablo mayor de San Juan Bautista de Estella. URANGA GALDIANO, J.E. Retablos navarros del Renacimiento. Pamplona, 1947, p. 50

${ }^{19}$ En las condiciones elaboradas por Pedro Antonio de Rada para el dorado del retablo de San Francisco Javier en la parroquia de Santiago de Calahorra (1742) se indica el baño de bronce en los fondos y el dorado bruñido en la talla "lo que ocasiona grande contraposición y ermosura, imitando el dorado de Italia, que son el despertador de esta profesión". SEGURA JIMENEZ J A. Diego de Camporredondo y el arte barroco y rococó en Calahorra y comarca. Logroño, 1994, pp. 43 y 179

${ }^{20}$ PASCUAL DIEZ, R. Arte de hacer el estuco jaspeado o de imitar jaspes a poca costa y con la mayor seguridad. Madrid, 1785. Facsimil. Valladolid, 1988

${ }^{21}$ Libro de recetas de policromía del siglo XVIII de la parroquia de Santa María de Sangüesa. Recogido por JIMENO JURIO, J.M. Pintores de Asiáin (Navarra), 1. Príncipe de Viana, 171 (1984), pp. 69 (composición del barniz), 70 (barniz de China) y 73 (sobre la elaboración del barniz de espiritu de vino)

${ }^{22}$ SANCHEZ-MESA MARTIN, D. "La policromía en las esculturas de Cano". Estudios del III Centenario de Alonso Cano en Granada. Granada, 1969, pp. 239-245. Sobre la policromía de tonos planos. Ibid. José Risueño, escultor y pintor granadino, 1665-1752. Granada, 1972, pp. 109-110. Policromía de tonos lisos

${ }^{23}$ PACHECO, F. Op. cit., pp. 494-502. Sobre las encarnaciones a pulimento y mate. Según Rocío Bruquetas, las buenas encarnaciones, principalmente las mates, permiten equiparar un oficio artesanal como es la pintura, dorado y estofado de imágenes, a la categoría de obra pictórica. BRUOUETAS, R. Técnicas y materiales de la pintura española en los Siglos de Oro. Fundación de Apoyo a la Historia del Arte Hispánico. Madrid, 2002, p.421

${ }^{24}$ Sirvan como ejemplos ilustrativos para el siglo XVII los inventarios de bienes de los pintores Juan de Frías Salazar de 1612 y 1622 (Archivo General de Navarra. Protocolos Notariales. Olite. Martín Garcia Moliner, 1612 y 1622) y Juan Claver de 1630 (Archivo Diocesano de Pamplona. Treviño. C/362, núm.1, fols. 18V, casa de Guetaria y 23V-24, casa de Pamplona) y el Libro de recetas de policromía del siglo XVIII de la parroquia de Santa Maria de Sangüesa. Recogido por JIMENO JURIO, J.M. Op. cit., pp. 69 y 71-72. En la reciente obra de Bruquetas sobre Técnicas y materiales de la pintura hispana de los siglos XVI y XVII se dedica un denso capitulo a los pigmentos, ilustrado excepcionalmente por fotografias de las materias primas de las que se extraen y cuadros cronológicos de su utilización (BRUQUETAS, R. Op.cit., pp.143-220)

${ }^{25}$ BERLINER, R. Modelos ornamentales de los siglos XV a XVIII, 2 vols. Barcelona, 1928. Texto: pp. 55, 59, 60-62, 65, 71 y 73. Láminas 186, 1 y 2, 202, 204, 207, 215, 217, 224B, 258-259 y 267. STELLA, J. Baroque ornament and designs (1658). New York, 1987

${ }^{26}$ BERLINER, R. Op. cit. Texto: pp. 92-96. Láminas 355-356, 361, 364, 367-373 y 378-385 ${ }^{27}$ Ibid. Texto: pp. 99-100 y 102-103. Láminas 390-394, 405-406 y 409

${ }^{28}$ PAEZ RIOS, E. Repertorio de grabados españoles de la Biblioteca Nacional, vol 1. Madrid, 1981, p. 215, lám. 444. ANSON NAVARRO, A. "Notas sobre Carlos Casanova, pintor de cámara y grabador aragonés". El arte en las Cortes europeas del siglo XVIII (Congreso de 1987). Madrid, 1989, p. 53

${ }^{29}$ BONET CORREA, A. Vida y obra de fray Matias de Irala, grabador y tratadista español del siglo XVIII. Madrid, 1979, pp. 36-37. Método sucinto y compendioso... Madrid, 1739, lám. 25 